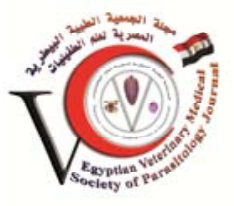

Original Article

\title{
Caligus lagocephali, Pillai, 1961 (Copepoda: Caligida: Siphonostomatida) from Morone labrax (as a new host) in Suez Canal area
}

Eman M. Youssef

Parasitology Department, Faculty of Veterinary Medicine, Suez Canal University

\begin{abstract}
:
In this study 200 marine fish samples, Morone labrax were collected from Suez Canal area and investigated for presence of Caligid parasites, in the period from January 2014 to December 2014. The study revealed that 80 out of $200(40 \%)$ were infested with a different Caligus species (C.minimus,C.longipedis and C.lagocephali). In respect to its incidence, it showed that Caligus species present all over the year, spring represent season of high prevalence while winter is the season of low prevalence. Morone labrax represent new host record for Caligus lagocephali with a percent of $1 \%$ infestion from total examined fish ( 2 out of 200$)$, C.lagocephali females only were obtained .It characterized by its creamy color, wide angle between frontal plates, well developed processes located proximally on the inner margin of the female maxilliped, sternal furca with tapering tines and the genital complex nearly 1.50 time longer than abdomen and has no distinct postero-lateral lobes. Genital complex and abdomen combined about two times longer than cephalothorax. Outer margin of the second endopodal segment of second leg densely ornamented with fine spinules.
\end{abstract}

Key words: Morone labrax, C. lagocephali, Suez Canal area, Egypt

\section{INTRODUCTION}

Caligid copepods, in a general known as sea lice, it's a members of family Caligidae Burmeister, 1835. The Caligidae currently comprises 28 genera and more than 400 species (Boxshall and Hulsey, 2004). Genus Caligus is the most species within the family Caligidae, established by Muller (1785). According to their mouth parts, the Caligids have tubular mouth, their mandibles are flat, long blades with the distal end carrying a row of teeth on one margin (Kabata, 1974). The Caligus species known as Productus-group created by Boxshall \& Gurney (1980). In 2003, Ho and Lin listed 16 valid species of this group then Boxshall and El-Rashidy (2009) were given additional characters help in identification of this group. Caligus lagocephali considered one of this group, recorded from Takifugu rubripes (Temminck and Schlgel, 1850), Takifugu niiphobles (Jordan and Snyder, 1901). All the reported hosts of C.lagocephali are tetraodontids (Yamaguti and Yamasu, 1959; Pilai, 1961; Ozak et al., 2012). In Egypt their were several authors recorded different Caligus species from different fish species; Paperna (1980) (Caligus minimus from Dicentrachus labrax in Bardawil lagoon), Badawy (1994) (Caligus carangis, sp.nov. from Caranx sem from Red Sea), Mohey and Abu EL-Wafa (1995) (Caligus curtus from captive Mugil and Sparus), Argun et al. (2010) (Caligus temnodontis from the bluefish Pomatomus saltatrix in Alexandria city), Eissa et al. (2012) (Caligus carangis from Morone labrax), Bayoumy et al. (2013) (Caligus kuwaitensis from Acanthopagrus bifasciatus), Noor El-Din et al. (2013) (Caligus minmus from Dicentrachus labrax and Caligus elongates from Mullet), Youssef (2014) (Caligus epidemicus from Mugil cephalus and Oreochromus niloticus at Suez Canal area), Youssef et al. (2014) (Caligus longipedis from Morone labrax at Suez Canal area) and Mahdy and Abu El Ezz (2015) (Caligus kuwaitnesis from Pagrus pagrus from Cairo). Caligus productus group having low data in Egypt. The aim of the present study are to throw the light on the Caligus infestation among Morone labrax, incidence and seasonal variations with special references to Caligus lagocephali as a new record from Morone labrax.

\section{MATERIALS AND METHOdS}

Two hundred marine fish samples, Morone labrax were collected a live from Suez Canal area, in the period from January 2014 to December 2014. the collected parasites were preserved in $70 \%$ ethyl alcohol, subsequently cleared in lactic acid for one hour, the preservation, dehydration and mounting of the parasites occur according to Pritchard and Kruse, 1982. Measurements were made using an ocular micro meter, Morphological terminology follows Boxshall (1990) and Huys \& Boxshall (1991). Host and fish names were identified according to fish base (Frose \& Pauly, 2009). 


\section{RESULTS}

Studying the Caligids infestation among marine fish, Morone labrax, it showed that 80 (40\%) out of 200 of the examined fish were infested with a different Caligus species which identified as C. minimus (Otto, 1821; Paperna, 1980); C. longipedis (Bassatte-Smith, 1898; Ganamuth, 1950) and C. lagocephali (Yamaguti and Yamasu, 1959; Pilai, 1961). C. lagocephali only represent $1 \%$ infestation from the total examined fish (2 out of 200).

Caligus species present all-over the year, high incidence were recorded in spring while winter was the Season of low incidence. The present study showed that Morone labrax represents a new host for Caligus lagocephali. The obtained $C$. lagocephali specimens were only females.

Order: Siphonostomatoida

Family: Caligidae Burmeister, 1835

Genus: Caligus Muller, 1785

Caligus lagocephali, Pillai, 1961

Morphology of Caligus lagocephali females (Fig. 1, 4): The parasite was found in the mouth cavities and skin of Morone labrax, it is creamy in color. The body dorsoventrally flattened, it measured $3.4 \mathrm{~mm}$ in average. Having a wide angle between frontal plate, cephalothorax measured $1.2 \times 1.1 \mathrm{~mm}$ in average and provided with conspicuous marginal membrane laterally and well defined striated border located ventrally internal to lateral margins of dorsal cephalothoracic shield, frontal plate carrying

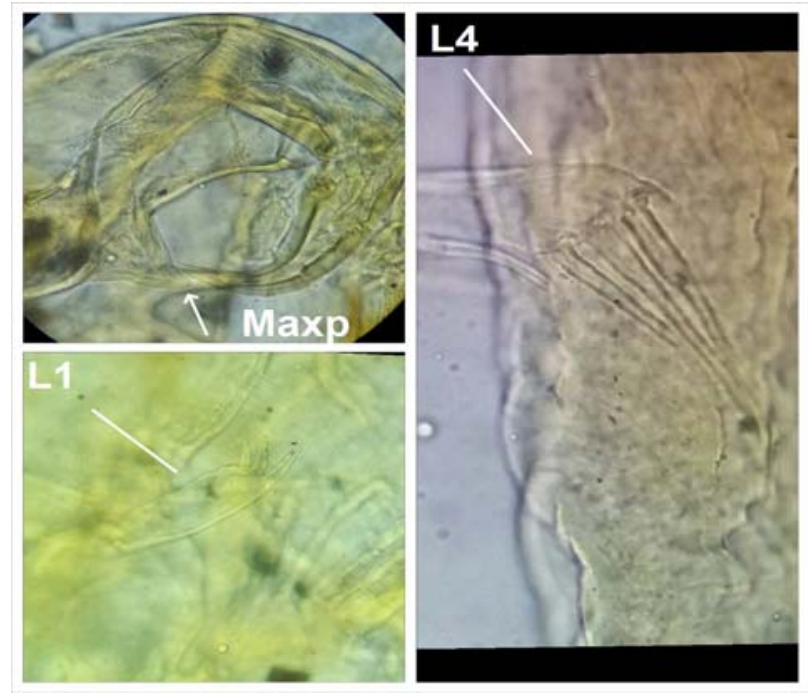

Figure 2A: Caligus lagocephali female:

L1: First leg shown no spine in its distal exopodal seg.

L4: fourth leg (shown formula spine 1-1V).

Maxp: maxilliped with large, well developed, tapring process proximally on medial margin.
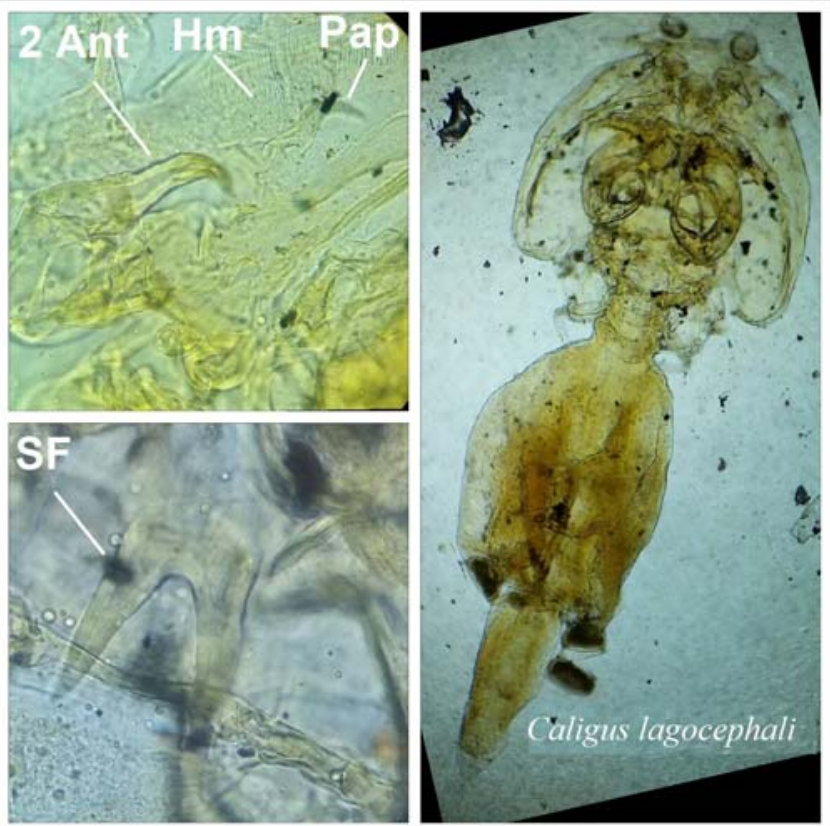

Figure 1: Caligus lagocephali female

2 ant: second antenna, Hm: hyaline membrane, Pap: postantennal process, SF: Sternal furca.

large lunules. Genital complex longer than wide, measured $1.25 \times 0.82 \mathrm{~mm}$ in average, it is 1.5 times longer than abdomen and has no distinct poster-lateral lobes. Abdomen longer than wide, measured $0.85 \times 0.32 \mathrm{~mm}$ in average, two segment, the first is the largest, the combined length of genital complex and abdomen approximately twice as long as cephalothorax. caudal rami longer than wide, $0.87 \times 0.065 \mathrm{~mm}$ with 6 pinnate setae, Maxilliped (Fig. 2b) with large, well developed, tapering

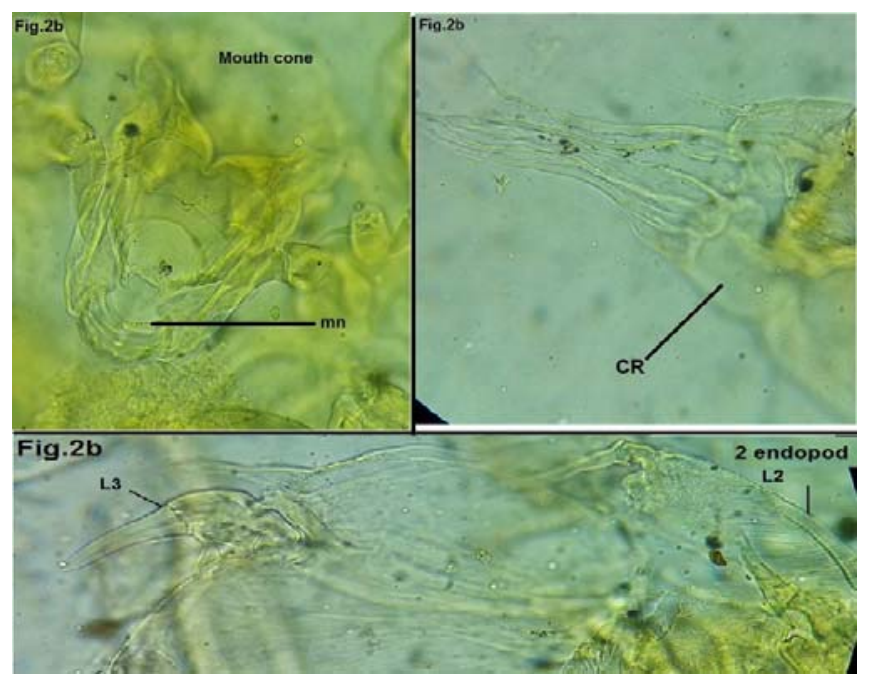

Figure 2B: Caligus lagocephali female:

CR: caudal ramus.

2 endopod, L2: outer margin of second endopodal segment of leg 2 densely ornamented with fine spinules.

-L3: process of third leg.

-Mn: serrated mandible. 


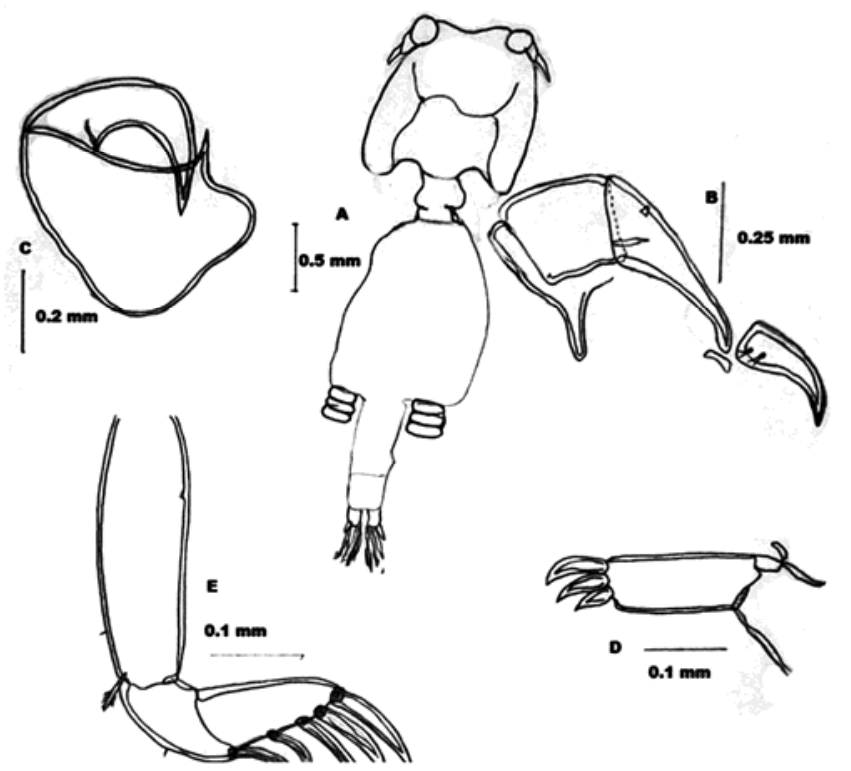

Figure 4: Caligus lagocephali: (A: whole parasite, B: second antenne, C: maxilliped, D: first leg, E: forth leg)

process proximally on medial margin. Sternal furca (Fig. 2a) with tapering tines. Leg 1 (Fig. 2b) with 2-segmented exopod and unsegmented vestigial endopod, distal exopodal segment without setae on posterior margin. Outer margin of the second endopodal segment of second leg densely ornamented with fine spinules. Second exopodal segment of fourth leg (Fig. 2b) with short outer margin spine and 3 long distal spines, increasing in length towards terminal spine. The male not recorded from the fish in this study.

\section{Discussion}

Caligus is considered important pathogen infesting marine fish, it cause severe damage upon the external surface of the fish. The prevalence of Caligus species infested the examined fish species, Morone labrax was $40 \%$, the result agreed with that given by Eissa et al. (2012). The seasonal variation showed that Spring Season was the Season of high record, in agreement with Paperna (1980), Eissa et al. (2012) and Noor El-Deen et al. (2013). Morone labrax infested with different species of Caligus, in this study Caligus lagocephali is one of this Caligids. It is one of the productus group created by Boxshall and Gurney (1980), characterized by loss of two and reduction or loss of the third plumose setae which carried on the posterior margin of the distal exopodal segment of the first leg. Boxshall and El-Rashidy (2009) were given additional characters help in identification of Productus group to include other typical character states such as: two-segmented abdomen of male, large lunules and two segmented exopod of fourth leg armed with $1,1 \mathrm{~V}$ spines and rare $(1,111)$, also give a key to the species of the Caligus productus-group (female only). Caligus lagocephali was recorded from Takifugu rubripes (Temminck and Schlgel, 1850), Takifugu niiphobles (Jordan and Snyder, 1901). All the reported hosts of $C$. lagocephali are tetraodontids (Yamaguti and Yamasu, 1959; Pilai, 1961; Ozak et al., 2012) so this record from Morone labrax consider first record. The striated ventral border extending around the lateral margins of the dorsal cephalothorcic shield internal to the margin membrane may enhance attachment to the surface of the hosts. The most distinguishing character of C.lagocephali is the well developed process located proximally on the inner margin of the female maxilliped which differentiate it from Caligus ariicolus which have the same ratio of abdomen and genital complex but maxilliped without proximal process on medial margin (Boxshall and El-Rashidy, 2009). The morphological features of our adult female revealed similarities both in shape and morphometrics to $C$. lagocephali as described by Yamaguti and Yamasu (1959). The body proportions are also in the range given by Boxshall and El-Rashidy (2009) and Ozak et al. (2012).

\section{Conclusion}

From this study it was concluded that Morone labrax was infested with different Caligus species with a percent of $40 \%$ and recorded as a new host for Caligus lagocephali with a percent of $1 \%$ infestation. C.lagocephali females only were obtained in this study and characterized by its creamy color, wide angle between frontal plates and Maxilliped with large, well developed, tapering process proximally on medial margin. Seasonal variation revealed that spring was the Season of high incidence.

\section{REFERENCES}

Argun, A.O; El-Rashidy, H. H; Ibrahim, D; Geof, A.B. (2010): The discovery of Caligus temnodontis Brian,1924 (Copepoda: Caligidae) from the bluefish Pomatomus saltatrix (Linnaeus) in the eastern Mediterranean Sea. Syst.Parasitol.76:223-230.

Badawy, G.A. (1994): Some studies on ectoparasites infesting marine fish in Egypt. Ph.D. Thesis, Parasitol.Dept. Fac. Vet. Med., Zag. Uni.

Bayoumy, E.M.; Baghdadi, H.B. and Hassanain, M.E.A. (2013): Light and Scan Electron Microscopes on Caligus kuwaitensis (Copepoda: Siphonostomatoida), from Arabian Gulf Doubleur Bream, Acanthopagrus bifasciatus, Off Dammam, Saudi Arabia, Australian J. Bas Appi Sci.,7,:974-978. 
Boxshall, G.A. (1990): The skeleton-musculature of siphonostomatoid, copepods, with an analysis of adaptive radiation in structure of the oral cone. Philosophical transactions of the Royal Society, London, Series B, 328, 167-212.

Boxshall, J. and Gurney, A.R. (1980): Description of two new and one poorly known species of the genus Caligus Muller, 1785 (Copepoda: Siphonostomatoida). Bulletin of the British Museum (Natural History). Zoology 39:161178.

Boxshall, G.A. and Halsey, S.H. (2004): An introduction to Copepod diversity. The Ray Society, London, 966 pp.

Boxshall, G.A. and El-Rashidy, H.H. (2009): A review of Caligus productus species group, with the description of a new synonymies and supplementary descriptions. Zoo taxa 2271:1-26.

Eissa, I.A.M.; Maather El-Lamie and Mona, Z. (2012): Studies on crustacean diseases of Sea bass, Morone labrax, in Suez Canal, Ismailia governorate. Life Science Journal 9(3):512-518.

Froese, R. \& Pauly, D.(Eds.) (2008): Fish Base. World Wide web electronic publication. Available from:http:// WWW.flshbase.org/(3 November 2008).

Gnanamuth, C.P (1950): Three new copepod parasites of the ribbon fish from South India. J.Parasitol. 38:113-119.

Ho, J. \& Lin, C.L. (2003): Solution to the taxonomic confusion surrounding Caligus epinepheli Yamaguti, a caligid copepod (Siphonostoatoida) parasitic on marine fishes. Zoological Studies, 42, 268-283.

Huys, R. and Boxshall, G.A. (1991): Copepoda Evolution. The Ray Society, London, pp 468.

Jordan and Snyder (1901): Cited in El-Rashidy, and Boxshall,(2009).

Kabata, Z. (1974): Mouth and mode of feeding of Caligidae (Copepoda) parasites of fishes as determined by light and Scanning electron microscopy. J. Fish. Res. Boa. Canada 31:1583-1588.

Mahdy, O.A. and Abu EL Ezz, N.M. (2015): Additional morphological information on young female Caligus kuwaitensis (Copepoda, Siphonostomoida) from Egyptain marine water fish(Pagrus pagrus). Aquac. Res. Development 6:3.
Mohey, El.S.E. and Salah, Abu El-Wafa. (1995): Pathological studies on an epidemic of Caligus curtus (Copepoda) among captive Mugil and Sparus in Egypt with reference to malathion control. Journal of Applied Aquculture 5(2):25-29.

Noor El-Deen, A.I.E.; Abeer,E; Mahmoud and Azza, H.M.H. (2013): Field studies of Caligus parasitic infections among cultured Sea bass (Dicentrus labrax) and Mullet (Mugil cephalus) in marine fish farms with emphasis on treatment trials. Global Veterinaria 11(5):511-520.

Ozak, A.A.; Demirkale, I. and Yanar, A. (2012): First record of two species of parasitic copepods on immigrant pufferfishes (Tetraodontiformes: Tetraodontidae) caught in the Estern Mediterranean Sea. Turkish J. Fisheries and Aquatic Sci.,12, 675-681.

Paperna, I. (1980): Study of Caligus minmus (Otto, 1821), (Caligidae Copepoda) infections of the Sea bass Dicentrarchus labrax (L.) in Bardawil lagoon. Ann Parasitol. Hum Comp, 1980;55(6):687-706.

Pillai, N.K. (1961): Copepoda parasitic on South Indian part 1 Caligidae. Bulletin of the Central research Institute, 8:87-130.

Pritchard, M.H, and Kruse, O.W. (1982): The collection and preservation of animal parasites. University of Nebraska press, 318 pp.

Temminck and Schlgel (1850): Cited in Boxshall, and ElRashidy, (2009).

Yamaguti, S. and Yamasu,T. (1959): Parasitic Copepoda and Branchiura of fishes. Interscience Publishers, New York, 1103 pp.

Youssef, E.M. (2014): Scanning Electron Microscopy on a parasitic Copepoda: Caligus epidemicus (Hewitt, 1971) at Suez Canal area. EVMSPJ.,153-159.

Youssef, E.M.; Sallam, N.H.; Essa, I.M. and Zaki, M.S. (2014): Parasitological studies on the crustacean parasites infesting some marine fishes at Suez Canal area, Egypt. EVMSPJ. 141-152. 